\title{
Corrosion Behavior of HA-316L SS Biocomposites in Aqueous Solutions
}

\author{
Alain Robin ${ }^{\mathrm{a} *}$, Gilbert Silva $^{\mathrm{b}}$,Jorge Luiz Rosa ${ }^{\mathrm{a}}$ \\ ${ }^{a}$ Departamento de Engenharia de Materiais, Escola de Engenharia de Lorena, \\ Universidade de São Paulo - USP, CP 116, CEP 12600-000, Lorena, SP, Brazil \\ 'Instituto de Engenharia Mecânica, Universidade Federal de Itajubá - UNIFEI, \\ CEP 37500 903, Itajubá, MG, Brazil
}

Received: February 18, 2013; Revised: April 19, 2013

\begin{abstract}
316L stainless steel and Hydroxyapatite (5, 20 and 50 wt. (\%) HA)-316L stainless steel composites were fabricated by mechanical alloying technique, pressing and sintering from $316 \mathrm{~L}$ and HA powders. The corrosion behavior of both sintered 316L and HA-316L composites was evaluated by electrochemical techniques in simulated body fluid (Ringer's solution) and in $0.1 \mathrm{M} \mathrm{HCl}$ solution which simulates occluded cell corrosion conditions. The results indicate that $316 \mathrm{~L}$ stainless steel and HA-316L composites are passive in Ringer's solution and active in $\mathrm{HCl}$ solution. All materials are highly corrosion resistant in Ringer's solution with corrosion current density in the order of $10^{-6} \mathrm{~A} \mathrm{~cm}^{-2}$ or less. Both 316L stainless steel and 5\% HA-316L composite present good corrosion resistance in $\mathrm{HCl}$ with corrosion current density in the order of $10^{-5} \mathrm{~A} \mathrm{~cm}^{-2}$. The corrosion resistance decreases with increasing HA content in both solutions.
\end{abstract}

Keywords: biocomposite, 316L SS, hydroxyapatite, corrosion

\section{Introduction}

316L austenitic stainless steel (316L SS) is widely used as surgical implant material due to its biocompatibility, corrosion resistance and good mechanical strength ${ }^{1}$. Unfortunately, 316L steel only forms weak mechanical bond with the bone tissue due to its biological inertness, which turns difficult the fixing of implant to live bone. In order to improve the osseointegration of these implants, different studies were performed on the deposition of hydroxyapatite (HA) on stainless steel ${ }^{2-5}$. Indeed, $\mathrm{HA}\left(\mathrm{Ca}_{10}\left(\mathrm{PO}_{4}\right)_{6}(\mathrm{OH})_{2}\right)$ has a similar chemical composition and crystallographic structure as the natural apatite of human body bone and consequently can form strong bonds with the bone. Simultaneously, the HA coating helps to prevent the release of metal ions from the steel implant and their accumulation in the internal organs. Another alternative to improve the interaction between the steel implant and the bone is the development of 316L steel based biocomposites containing $\mathrm{HA}^{6-10}$. Fan et al. ${ }^{9}$ studied the formation of bone-like apatite on HA/316L SS composites in simulated body fluid (SBF) and proved that the composites are excellent bioactive materials. Nevertheless, HA is brittle and the mechanical resistance of the HA-316L composites is lower than that of $316 \mathrm{~L}$ stainless steel ${ }^{7}$. It is well known that stainless steels are generally passive in neutral media but are susceptible to pitting and crevice corrosion in chloride media. These forms of corrosion are associated to local acidification and generally lead to a severe localized active dissolution ${ }^{11}$.

Tulinski ${ }^{12,13}$ showed that HA addition improved the corrosion resistance of HA/ nitrided nickel-free austenitic

*e-mail: alain@demar.eel.usp.br stainless steel in Ringer's solution. No work was found about the corrosion resistance of HA/316L SS composites.

This work aimed to study the corrosion behavior of HA/316L SS biocomposites in simulated physiological solution (Ringer's solution) and under simulated occluded cell corrosion conditions $(0.1 \mathrm{M} \mathrm{HCl})$. The investigation was based on electrochemical techniques.

\section{Experimental}

\subsection{Material}

HA powder was prepared by wet precipitation using $\mathrm{Ca}\left(\mathrm{NO}_{3}\right)_{2} \cdot 4 \mathrm{H}_{2} \mathrm{O}$ and $\mathrm{H}_{3} \mathrm{PO}_{4}$ reagents, followed by filtration, calcination at $900{ }^{\circ} \mathrm{C}$ for $2 \mathrm{~h}$ and deagglomeration. The whole procedure of preparation was detailed elsewhere ${ }^{14}$. 316L stainless steel powder (size ranging from 5 to $30 \mu \mathrm{m}$ ) and HA powder were mixed in the following proportions, $95 / 5,80 / 20$ and 50/50 weight percent. The mixtures were homogenized for $10 \mathrm{~h}$ using a dry planetary ball mill (Fritsch, model Pulverisette 5) under the following conditions: stainless steel balls (18 mm-diameter) and vessel (250 mL), ball to powder mass ratio 10:1, speed $120 \mathrm{rpm}$. Then, the mixtures were uniaxially pressed under $32 \mathrm{MPa}$ pressure and then isostatically pressed under $200 \mathrm{MPa}$ pressure. The densified mixtures were heated under vacuum in a resistive furnace up to $1200{ }^{\circ} \mathrm{C}$ at a $10{ }^{\circ} \mathrm{C} / \mathrm{min}$ rate, maintained at $1200^{\circ} \mathrm{C}$ for $2 \mathrm{~h}$ and then naturally cooled to room temperature.

\subsection{Electrochemical study}

Cylindrical slices (of nearly $9 \mathrm{~mm}$ diameter and $3 \mathrm{~mm}$ thickness) were cut from the sintered $316 \mathrm{~L}$ and HA-316L 
composite rods and then mounted in resin. The cross-section of the electrodes (about $0.7 \mathrm{~cm}^{2}$ area) was mechanically ground up to a 1200-grit finish, rinsed with distilled water and dried.

The electrolytic solutions used for the electrochemical study were the naturally aerated Ringer's solution (whose composition is: $8.6 \mathrm{~g} \mathrm{NaCl}+0.3 \mathrm{~g} \mathrm{KCl}+0.33 \mathrm{~g} \mathrm{CaCl}_{2}-\mathrm{H}_{2} \mathrm{O}$ in $1000 \mathrm{~mL}$ deionized water) and the naturally aerated $0.1 \mathrm{M}$ $\mathrm{HCl}$ solution. The counter electrode was a square-shaped platinum sheet of $18 \mathrm{~cm}^{2}$ area and the reference electrode was the saturated calomel electrode (SCE). The experiments were performed at room temperature.

Open-circuit potential, electrochemical impedance spectroscopy (EIS) and polarization measurements were made using the Electrochemical Interface SOLARTRON mod. 1287A and the Frequency Response Analyzer SOLARTRON mod. 1260 A, controlled by the Ecorr/Zplot SOLARTRON mod. $125587 \mathrm{~S}$ software. Triplicate assays were performed and reproducibility was verified.

Prior to polarization experiments, the working electrodes were immersed in the solutions for $3 \mathrm{~h}$, taking the moment of immersion as zero time. Then, impedance measurements at open-circuit potential were made using a sinusoidal signal of $10 \mathrm{mV}$ amplitude and frequencies in the $0.01 \mathrm{~Hz}-100 \mathrm{kHz}$ range. Cathodic and anodic polarization was then carried out potentiodynamically with $1 \mathrm{mV} \mathrm{s}^{-1}$ sweep rate. After each run, the samples were reground with emery paper to a 1200-grit finish in order to remove any product formed on the metal surface which could affect the following tests, rinsed with distilled water and dried.

\section{Results and Discussion}

\subsection{Microstructure of HA/316L stainless steel biocomposites}

Figure 1 shows micrographs of polished surfaces of the investigated materials obtained by scanning electron microscopy (SEM). The microstructure of sintered $316 \mathrm{~L}$ presents austenitic grains and pores (black spots) (Figure 1a). The microstructure of 5\% HA-316L composite is constituted of austenitic grains (grey regions), HA (light regions), an eutectic phase at the grains boundaries (represented by E letter) and pores (Figure 1b). The eutectic phase was also observed by Szewczyk-Nykie ${ }^{10}$. It can be observed that HA was partially removed during grinding, leaving many holes. The chemical analysis by energy dispersive spectroscopy (EDS) of the austenitic grains in 5\% HA-316L composite (P2 and P3-Figure 1b) showed the presence of the constituent elements of $316 \mathrm{~L}$ stainless steel, Fe, Cr, Ni and Mo and some trace of P (Table 1). P element is not found in sintered 316L steel (P1-Figure 1a). This means that some phosphorus diffused from HA phase into austenitic grains during sintering of the composites ${ }^{10}$. In the light regions (P4 and P5-Figure 1b), large amount of $\mathrm{Ca}$ and $\mathrm{O}$ are present, as well as $\mathrm{Fe}$ and $\mathrm{Cr}$ (Table 1). Thus, it seems that $\mathrm{Cr}$ and $\mathrm{Fe}$ have migrated from austenitic phase. The eutectic phase (P6-Figure 1b) contains significative amounts of $\mathrm{Fe}, \mathrm{Cr}, \mathrm{Mo}, \mathrm{Ni}$ and $\mathrm{P}$ and some trace of $\mathrm{Ca}$ (Table 1), and can be the result of some chemical reaction occured during sintering.
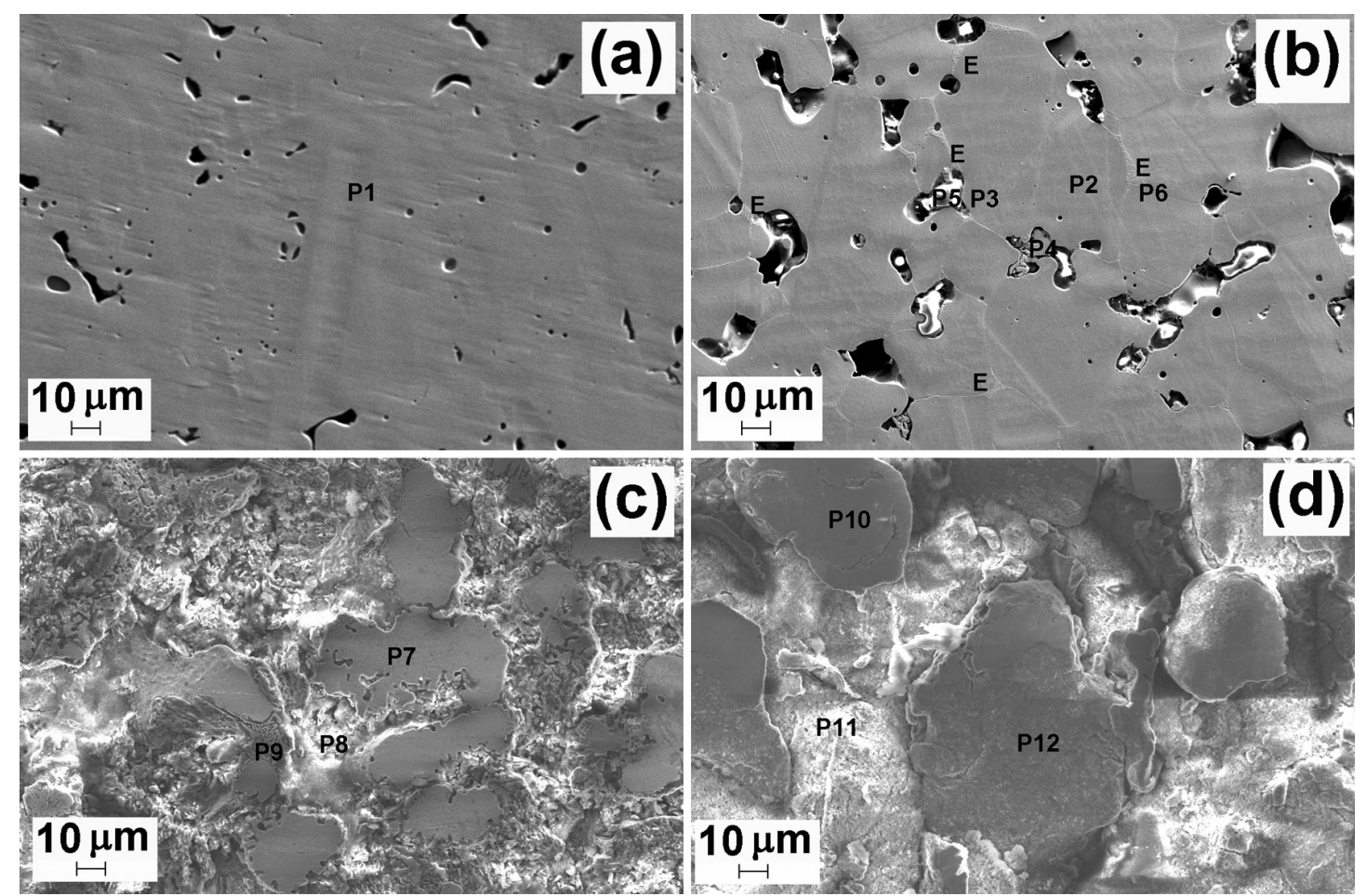

Figure 1. Microstructure of sintered (a) 316L stainless steel, (b) 5\% HA-316L, (c) 20\% HA-316L and (d) 50\% HA-316L composites. 
Table 1. Microanalysis by EDS of sintered 316L and HA-316L composites (wt. (\%)).

\begin{tabular}{|c|c|c|c|c|c|c|c|c|}
\hline \multirow{2}{*}{\multicolumn{2}{|c|}{ Material / Region }} & \multicolumn{7}{|c|}{ Element } \\
\hline & & \multirow{2}{*}{$\frac{\mathbf{F e}}{66.2}$} & \multirow{2}{*}{$\frac{\mathrm{Cr}}{17.9}$} & \multirow{2}{*}{$\begin{array}{c}\mathbf{N i} \\
13.7\end{array}$} & \multirow{2}{*}{$\frac{\text { Mo }}{2.2}$} & \multirow{2}{*}{$\frac{\mathbf{P}}{-}$} & \multirow{2}{*}{$\begin{array}{c}\mathbf{C a} \\
-\end{array}$} & \multirow{2}{*}{$\begin{array}{l}\mathbf{O} \\
-\end{array}$} \\
\hline $316 \mathrm{~L}$ & P1-Figure 1a & & & & & & & \\
\hline \multirow{6}{*}{$5 \% \mathrm{HA}-316 \mathrm{~L}$} & P2-Figure 1b & 66.6 & 17.7 & 13. 6 & 1.7 & 0.4 & - & - \\
\hline & P3-Figure 1b & 66.3 & 17.9 & 13.3 & 2.0 & 0.5 & - & - \\
\hline & P4-Figure 1b & 3.4 & 2.8 & - & - & - & 25.0 & 68.8 \\
\hline & P5-Figure 1b & 0.8 & 26.7 & - & - & - & 31.3 & 41.2 \\
\hline & P6-Figure 1b & 47.3 & 27.1 & 10.1 & 7.9 & 7.4 & 0.2 & - \\
\hline & P7-Figure 1c & 76.2 & 8.1 & 14.9 & - & 0.8 & & \\
\hline \multirow{3}{*}{$20 \% \mathrm{HA}-316 \mathrm{~L}$} & P8-Figure 1c & 10.8 & 16.5 & 2.6 & - & - & 10,0 & 60.1 \\
\hline & P9-Figure 1c & 30.8 & 18.9 & 8.0 & 7.6 & 16.5 & 2.5 & 15.7 \\
\hline & P10-Figure 1d & 69.2 & 17.0 & 13.7 & - & 0.1 & - & - \\
\hline \multirow[t]{2}{*}{$50 \%$ HA-316L } & P11-Figure 1d & 3.5 & 1.7 & - & - & 17.6 & 35.6 & 41.6 \\
\hline & P12-Figure 1d & 47.4 & 24.0 & 8.7 & - & 1.0 & 2.8 & 16.1 \\
\hline
\end{tabular}

Phosphorus has also diffused from HA phase into austenitic grains during sintering of the $20 \%$ and $50 \%$ HA-316L composites (P7-Figure 1c and P10-Figure 1d, Table 1). In the 50\% HA-316L composite some steel grains are rich in $\mathrm{Ca}$ and $\mathrm{O}$ too (P12-Figure 1d, Table 1) and in the $\mathrm{HA}$ regions, besides the presence of $\mathrm{Ca}, \mathrm{P}$ and $\mathrm{O}, \mathrm{Fe}$ and $\mathrm{Cr}$ were also detected (P11-Figure 1d, Table 1). This could be related to some reaction between $316 \mathrm{~L}$ steel and HA during sintering ${ }^{7}$. Similarly, in the HA regions of the $20 \%$ HA-316 composite, $\mathrm{Fe}, \mathrm{Cr}$ and $\mathrm{Ni}$ are present (P8-Figure 1c, Table 1). Some regions with high concentrations of $\mathrm{Fe}, \mathrm{Cr}$, $\mathrm{Ni}, \mathrm{Mo}, \mathrm{Ca}, \mathrm{P}$ and $\mathrm{O}$ and that look like an eutectic phase (E) were also observed in the $20 \%$ HA-316L composites (P 9-Figure 1c, Table 1).

Besides diffusion, possible phase transformation during sintering could be considered. The $\mathrm{X}$ ray diffraction patterns of $316 \mathrm{~L}$ and composite samples only revealed the peaks of the austenite phase (JCPDS card number 33-0397) ${ }^{15}$, and also peaks of HA (JCPDS card number 09-0432) ${ }^{15}$ for the composites, which attests that the austenite phase did not undergoe transformation during sintering.

\subsection{Corrosion behavior of $H A / 316 L$ biocomposites in Ringer's solution}

The open-circuit potentials (OCPs) of 316L and HA/316L composites tended to stabilize before $3 \mathrm{~h}$ immersion in Ringer's solution (Figure 2). The values of all OCPs are found in the stability regions of $\mathrm{Fe}_{2} \mathrm{O}_{3}$ and $\mathrm{Cr}_{2} \mathrm{O}_{3}$ of the $\mathrm{Fe}-\mathrm{H}_{2} \mathrm{O}$ and $\mathrm{Cr}-\mathrm{H}_{2} \mathrm{O}$ Pourbaix' diagrams ${ }^{16}$, which shows the passive behavior of all materials. The OCPs values measured at $3 \mathrm{~h}$ ( $\mathrm{E}_{\text {corr }}$ corrosion potentials) shifted in the negative direction as the HA content increased (Table 2), which means that the addition of HA turned the materials less noble. Tulinski ${ }^{13}$ found the same tendency for HA $(0$, 5, 10 and 15 wt.\%) -nickel free stainless steel composites in Ringer's solution.

The polarization curves of $316 \mathrm{~L}$ stainless steel and HA316L composites in Ringer's solution at room temperature are presented in Figure 3. The shape of the curves is very similar for all materials, which shows that the anodic and cathodic reactions occurring on the different surfaces

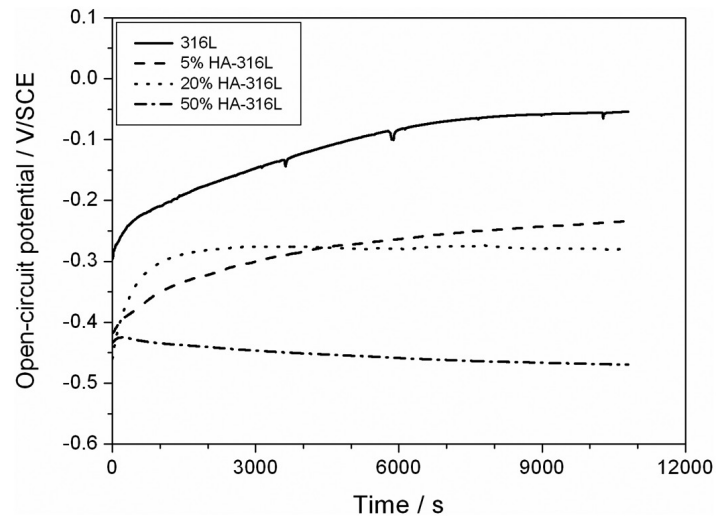

Figure 2. Variation of open-circuit potential with time for sintered 316L stainless steel and HA-316L composites in Ringer's solution at room temperature.

are identical. The cathodic domain is related first to the reduction of dissolved oxygen and at lower potentials to the simultaneous reduction of water. The anodic branch presents a pseudo-plateau corresponding to the passive region. It was shown that the passive film on 316 stainless steel is mainly constituted of chromium oxide and lower contents of iron and molybdenum oxides, without presence of nickel oxide ${ }^{17}$. For higher potentials the anodic current density increases strongly due to the breaking of passivity related to pitting corrosion.

Nevertheless, the anodic and cathodic current densities increase as the HA content in the composites increases.

Accordingly to the variation of $\mathrm{E}_{\text {corr }}$ values, the nullcurrent potential $\mathrm{E}_{\mathrm{i}=\mathbf{0}}$ shifted in the negative direction as the HA content increased (Figure 3 and Table 2). The $\mathrm{E}_{\mathrm{i}=\mathbf{0}}$ values are more negative than the $\mathrm{E}_{\text {corr }}$ ones, which may be due to the partial removal of oxide passive film during the cathodic polarization.

The corrosion current density $i_{\text {corr }}$ determined by extrapolation of the cathodic Tafel lines to the null-current potential are reported in Table 2 for the four materials. A significant decrease in corrosion resistance is observed for 
Table 2. Corrosion potential $\left(\mathrm{E}_{\text {corr }}\right)$, null-current potential $\left(\mathrm{E}_{\mathrm{i}=0}\right)$, breakdown potential $\left(\mathrm{E}_{\mathrm{b}}\right)$, corrosion current density $\left(\mathrm{i}_{\text {corr }}\right)$, passive current density ( $\mathrm{i}_{\text {pass }}$ measured at the middle of the passive region) and impedance modulus $(|\mathrm{Z}|$ measured at $0.01 \mathrm{~Hz}$ ) of sintered 316L stainless steel and HA-316L composites in Ringer's solution at room temperature.

\begin{tabular}{lcccc}
\hline & $\mathbf{3 1 6 L}$ & $\mathbf{5 \% H A - 3 1 6 L}$ & $\mathbf{2 0 \% H A - 3 1 6 L}$ & $\mathbf{5 0 \% H A - 3 1 6 L}$ \\
\hline $\mathrm{E}_{\text {corr }} / \mathrm{V} / \mathrm{SCE}$ & $-0.054 \pm 0.008$ & $-0.229 \pm 0.012$ & $-0.304 \pm 0.025$ & $-0.488 \pm 0.029$ \\
$\mathrm{E}_{\mathrm{i}=\mathbf{0}} / \mathrm{V} / \mathrm{SCE}$ & $-0.173 \pm 0.025$ & $-0.398 \pm 0.018$ & $-0.516 \pm 0.024$ & $-0.659 \pm 0.041$ \\
$\mathrm{E}_{\mathbf{b}} / \mathrm{V} / \mathrm{SCE}$ & $0.376 \pm 0.033$ & $0.214 \pm 0.019$ & $-0.080 \pm 0.043$ & $-0.107 \pm 0.006$ \\
$\mathrm{i}_{\text {corr }} / \mathrm{A} \mathrm{cm}^{-2}$ & $(1.8 \pm 0.4) \times 10^{-7}$ & $(6.7 \pm 1.2) \times 10^{-7}$ & $(22.2 \pm 0.8) \times 10^{-7}$ & $(31.0 \pm 3.5) \times 10^{-7}$ \\
$\mathrm{i}_{\text {pass }} / \mathrm{A} \mathrm{cm}^{-2}$ & $(2.05 \pm 0.30) \times 10^{-6}$ & $(1.21 \pm 0.03) \times 10^{-6}$ & $(5.06 \pm 0.49) \times 10^{-6}$ & $(14.20 \pm 4.6) \times 10^{-6}$ \\
$|\mathrm{Z}|_{\mathrm{f}=0.01 \mathrm{~Hz}} / \mathrm{k} \Omega \mathrm{cm}^{2}$ & $111.0 \pm 23.4$ & $113.7 \pm 8.3$ & $11.1 \pm 3.8$ & $7.6 \pm 2.5$ \\
\hline
\end{tabular}

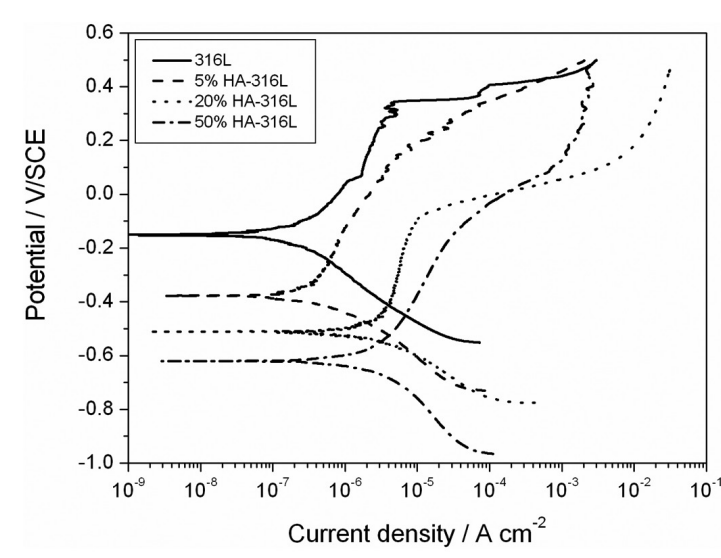

Figure 3. Polarization curves of sintered 316L stainless steel and HA-316L composites in Ringer's solution at room temperature.

the 20 and $50 \%$ HA-316L composites. This may be related to the enrichment of HA phase with $\mathrm{Cr}$. Nevertheless, the corrosion current densities are in the order of $10^{-6} \mathrm{~A} \mathrm{~cm}^{-2}$ or less for all materials, which is characteristic of corrosion resistant materials. Tulinski ${ }^{13}$ showed that the corrosion resistance of HA-nickel free stainless steel composites increases with increasing HA content between 0 and $10 \%$ but further decreases for $15 \%$ HA-SS composite.

The passive current density $i_{\text {pass }}$ measured for 20 and $50 \%$ HA-316L composites is also higher than that obtained for 316L steel and 5\% HA-316L composite which depicts a lower protective character of their passive film (Table 2).

The breakdown potential $\mathrm{E}_{\mathrm{b}}$ (measured when the anodic current density suddently increases) shifts in the negative direction as the HA content increases, which is characteristic of a higher susceptibility to pitting (Table 2).

The values of $\mathrm{E}_{\text {corr }}, \mathrm{i}_{\text {corr }}, \mathrm{i}_{\text {pass }}$ and $\mathrm{E}_{\mathbf{b}}$ for $316 \mathrm{~L}$ steel are close to the values obtained by Talha ${ }^{18}$ in Ringer's solution containing $\mathrm{NaHCO}_{3}$ at $37^{\circ} \mathrm{C}$.

The spontaneous corrosion behavior of metals and alloys is better evaluated from the impedance measurements at corrosion potential. Indeed, the use of this technique only disturbs the potential from $+10 \mathrm{mV}$ to $-10 \mathrm{mV}$ around the spontaneous corrosion potential. Thus, during the measurements, the electrode surface is only slightly changed.

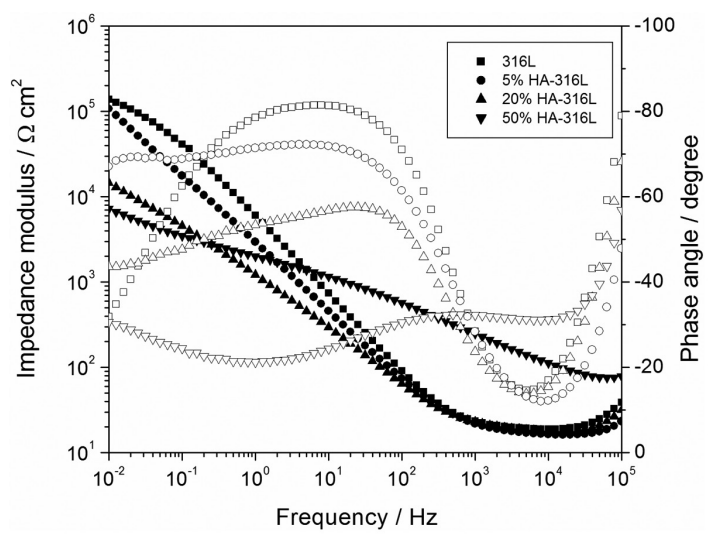

Figure 4. Bode diagrams of sintered 316L stainless steel and HA316L composites in Ringer's solution at room temperature and at corrosion potential.

Figure 4 shows the Bode diagrams obtained for $316 \mathrm{~L}$ stainless steel and HA-316L composites in Ringer's solution at corrosion potential. For $316 \mathrm{~L}$ stainless steel, the impedance diagram presents one time constant. The slope of $\log$ (Impedance) versus log (Frequency) is close to -1 and the phase angle close to $-90^{\circ}$ on a large frequency range, which is characteristic of passive material. For the HA-316L composites, Bode diagrams with two time constants were obtained. Only the 5\% HA-316L composite maintains a behavior close to that of $316 \mathrm{~L}$ steel, i.e. high impedance values, slope of log (Impedance) versus log (Frequency) close to -1 and a phase angle around $-70^{\circ}$ on a large frequency range.

The corrosion resistance of the materials can be estimated for comparison by the values of impedance modulus at low frequencies (Table 2). 316L stainless steel and $5 \%$ HA-316L composite present values close to $10^{5} \Omega$ $\mathrm{cm}^{2}$ and 20 and 50\% HA-316L composites values around $10^{4} \Omega \mathrm{cm}^{2}$.

Though there is a clear evidence that corrosion resistance decreases with increasing HA content, the values of $i_{\text {corr }}, i_{\text {pass }}$ and $Z$ (at low frequencies) must be considered carefully. Indeed, the porosity of the composites also increases with increasing HA content (Figure 1), which can lead to a significant error on the measured sample area exposed to the corrosive medium, and consequently to an error on $\mathrm{i}_{\text {corr }}, \mathrm{i}_{\text {pass }}$ and $\mathrm{Z}$ values. 


\subsection{Corrosion behavior of $H A / 316 L$ biocomposites in $0.1 \mathrm{M} \mathrm{HCl}$ solution}

The open-circuit potentials (OCPs) of $316 \mathrm{~L}$ and HA$316 \mathrm{~L}$ composites also stabilized before $3 \mathrm{~h}$ immersion in $0.1 \mathrm{M} \mathrm{HCl}$ solution (Figure 5). The values of all OCPs are found in the stability regions of $\mathrm{Fe}^{2+}$ and $\mathrm{Cr}^{3+}$ ions of the $\mathrm{Fe}-\mathrm{H}_{2} \mathrm{O}$ and $\mathrm{Cr}-\mathrm{H}_{2} \mathrm{O}$ Pourbaix' diagrams ${ }^{16}$, which depicts the active behavior of all materials. The OCPs values measured at $3 \mathrm{~h}$ (corrosion potentials) shifted in the negative direction

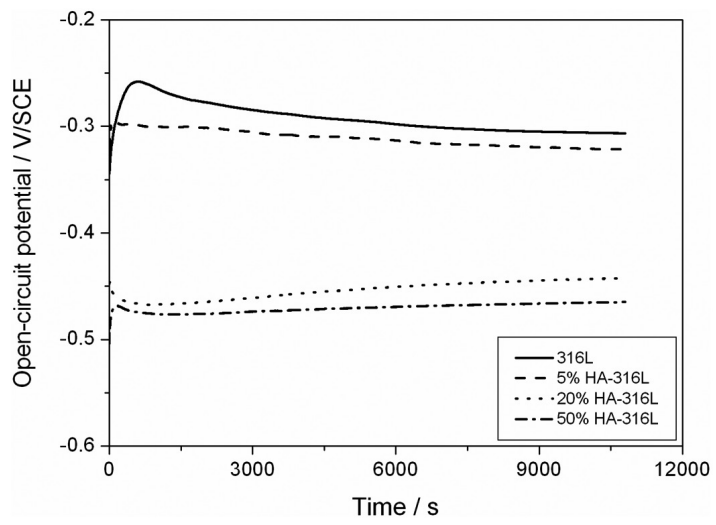

Figure 5. Variation of open-circuit potential with time for sintered $316 \mathrm{~L}$ stainless steel and $\mathrm{HA}-316 \mathrm{~L}$ composites in $0.1 \mathrm{M} \mathrm{HCl}$ solution at room temperature.

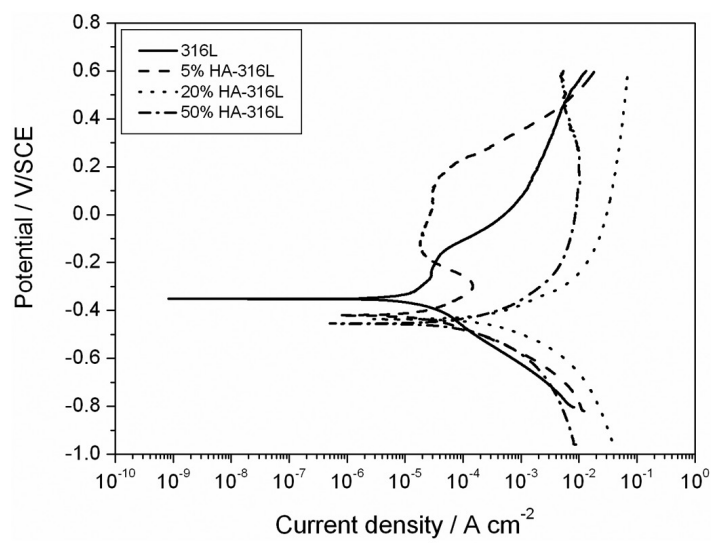

Figure 6. Polarization curves of sintered $316 \mathrm{~L}$ stainless steel and HA-316 composites in $0.1 \mathrm{M} \mathrm{HCl}$ solution at room temperature. as the HA content increased (Table 3), which means that the addition of $\mathrm{HA}$ also turned the materials more active in $\mathrm{HCl}$ solution. It can be noted that the corrosion potentials of both $316 \mathrm{~L}$ and $5 \% \mathrm{HA}-316 \mathrm{~L}$ composite are very close. The same occurred for both $20 \%$ and $50 \%$ HA- $316 \mathrm{~L}$ composites. The $\mathrm{E}_{\text {corr }}$ values are generally more negative than those measured in Ringer's solution, which shows that the materials are less noble in $\mathrm{HCl}$ solution.

The polarization curves of $316 \mathrm{~L}$ stainless steel and HA-316L composites in $0.1 \mathrm{M} \mathrm{HCl}$ solution at room temperature are shown in Figure 6. The cathodic branches are related to hydrogen evolution. It seems that the kinetics of $\mathrm{H}^{+}$reduction on $316 \mathrm{~L}$ steel is controlled by activation but is diffusion-controlled on the HA-316L composites. The anodic curves present different shapes. $316 \mathrm{~L}$ steel showed a narrow passive region between nearly -0.260 and $-0.160 \mathrm{~V} /$ SCE followed by the film breakdown above $-0.160 \mathrm{~V} / \mathrm{SCE}$. For the 5\% HA-316L composite, the cathodic polarization seems to have led to the dissolution of the passive film since during the anodic polarization, the curve presented an anodic peak followed by a wide passive region between -0.150 and $0.150 \mathrm{~V} / \mathrm{SCE}$. The corrosion and passive current densities are similar for both $316 \mathrm{~L}$ and $5 \%$ HA-316L composite (Table 3). Nevertheless, the passive film on the $5 \%$ HA-316L surface only undergoes pitting corrosion for potentials above $0.150 \mathrm{~V} / \mathrm{SCE}$. The anodic branches for both 20 and $50 \%$ HA-316L composites are very similar. Both materials are active and no passivation is observed. Thus $\mathrm{E}_{\mathbf{b}}$ and $\mathrm{i}_{\text {pass }}$ values

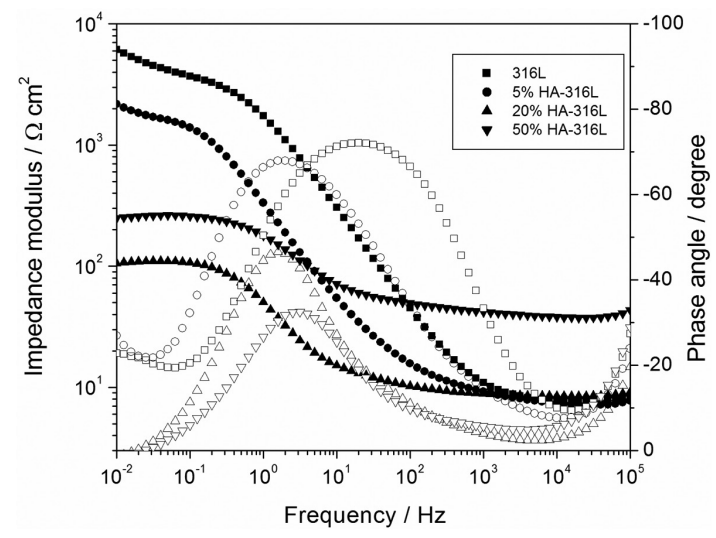

Figure 7. Bode diagrams of sintered 316L stainless steel and HA$316 \mathrm{~L}$ composites in $0.1 \mathrm{M} \mathrm{HCl}$ solution at room temperature and at corrosion potential.

Table 3. Corrosion potential $\left(\mathrm{E}_{\text {corr }}\right)$, null-current potential $\left(\mathrm{E}_{\mathrm{i}=0}\right)$, breakdown potential $\left(\mathrm{E}_{\mathrm{b}}\right)$, corrosion current density ( $\left.\mathrm{i}_{\text {corr }}\right)$, passive current density ( $\mathrm{i}_{\text {pass }}$ measured at the middle of the passive region) and impedance modulus $(|\mathrm{Z}|$ measured at $0.01 \mathrm{~Hz}$ ) of sintered $316 \mathrm{~L}$ stainless steel and $\mathrm{HA}-316 \mathrm{~L}$ composites in $0.1 \mathrm{M} \mathrm{HCl}$ solution at room temperature.

\begin{tabular}{lcccc}
\hline & 316L & $\mathbf{5 \% H A - 3 1 6 L}$ & $\mathbf{2 0 \% H A - 3 1 6 L}$ & $\mathbf{5 0 \% H A - 3 1 6 L}$ \\
\hline $\mathrm{E}_{\text {corr }} / \mathrm{V} / \mathrm{SCE}$ & $-0.310 \pm 0.006$ & $-0.332 \pm 0.015$ & $-0.442 \pm 0.001$ & $-0.462 \pm 0.002$ \\
$\mathrm{E}_{\mathrm{i}=\mathbf{0}} / \mathrm{V} / \mathrm{SCE}$ & $-0.359 \pm 0.012$ & $-0.424 \pm 0.006$ & $-0.435 \pm 0.001$ & $-0.456 \pm 0.002$ \\
$\mathrm{E}_{\mathrm{b}} / \mathrm{V} / \mathrm{SCE}$ & $-0.158 \pm 0.012$ & $0.156 \pm 0.005$ & $*$ & $*$ \\
$\mathrm{i}_{\text {corr }} / \mathrm{A} \mathrm{cm}^{-2}$ & $(2.3 \pm 0.4) \times 10^{-5}$ & $(5.0 \pm 2.0) \times 10^{-5}$ & $(42.0 \pm 11.3) \times 10^{-5}$ & $(21.0 \pm 2.8) \times 10^{-5}$ \\
$\mathrm{i}_{\text {pass }} / \mathrm{A} \mathrm{cm}^{-2}$ & $(3.1 \pm 0.4) \times 10^{-5}$ & $(4.6 \pm 2.5) \times 10^{-5}$ & $*$ & $*$ \\
$|\mathrm{Z}|_{\mathrm{f}=\mathbf{0 . 0 1 ~ H z}} / \Omega \mathrm{cm}^{2}$ & $5469 \pm 962$ & $1580 \pm 840$ & $98 \pm 10$ & $295 \pm 66$ \\
\hline
\end{tabular}

*no passive region and consequently no breakdown are observed for 20 and 50\% HA-316L composites. 
are not available for these materials. Their corrosion current densities are one order of magnitude higher than the values measured for 316L and 5\% HA-316L composite (Table 3).

Figure 7 shows the Bode diagrams obtained for $316 \mathrm{~L}$ stainless steel and $\mathrm{HA}-316 \mathrm{~L}$ composites in $0.1 \mathrm{M} \mathrm{HCl}$ solution at corrosion potential. Both $316 \mathrm{~L}$ stainless steel and 5\% HA-316L composite show a slope of log (Impedance) versus $\log$ (Frequency) close to -1 and a phase angle near $-70^{\circ}$ in the intermediary frequency range frequency range.

The corrosion resistance of the materials can be estimated by the values of impedance modulus at low frequencies (Table 3). 316L stainless steel and 5\% HA-316L composite present values in the order of $10^{3} \Omega \mathrm{cm}^{2}$ and 20 and $50 \%$ HA- 316L composites values around $10^{2} \Omega \mathrm{cm}^{2}$.

\section{References}

1. Stainless Steels. 3rd ed. Materials Park: ASM International; 1999.

2. Javidi M, Javadpour S, Bahrololoom ME and Ma J. Electrophoretic deposition of natural hydroxyapatite on medical grade 316L stainless steel. Materials Science and Engineering C. 2008; 28:1509-15. http://dx.doi.org/10.1016/j. msec.2008.04.003

3. Gopi D, Prakash V, Collins A and Kavitha L. Evaluation of hydroxyapatite coatings on borate passivated 316L SS in Ringer's solution. Materials Science and Engineering C. 2009; 29:9558. http://dx.doi.org/10.1016/j.msec.2008.08.020

4. Javidi M, Bahrololoom ME, Javadpour S and Ma J. In vitro electrochemical evaluation and phase purity of natural hydroxyapatite coating on medical grade 316L stainless steel. Materials and Corrosion. 2009; 60:336-43. http://dx.doi. org/10.1002/maco.200805117

5. Aksakal B, Gavgali M and Dikici B. The Effect of Coating Thickness on Corrosion Resistance of Hydroxyapatite Coated $\mathrm{Ti}_{6} \mathrm{~A}_{14} \mathrm{~V}$ and 316L SS Implants. Journal of Materials Engineering and Performance. 2010; 19:894-9. http://dx.doi. org/10.1007/s11665-009-9559-7

6. Miao X. Observation of microcracks formed in HA-316L composites. Materials Letters. 2003; 57:1848-53. http://dx.doi. org/10.1016/S0167-577X(02)01080-7

7. Zou J, Ruan J, Huang B, Liu J and Zhou X. Physico-chemical properties and microstructure of hydroxyapatite-316L stainless steel biomaterials. Journal of Central South University of Technology. 2004; 11:113-8. http://dx.doi.org/10.1007/s11771004-0024-3

8. Guo HB, Miao X, Chen Y, Cheang P and Khor KA. Characterization of hydroxyapatite- and bioglass $-316 \mathrm{~L}$ fibre composites prepared by spark plasma sintering. Materials Letters. 2004; 58:304-7. http://dx.doi.org/10.1016/S0167577X(03)00474-9

\section{Conclusions}

Sintered 316L stainless steel and 5, 20 and $50 \mathrm{wt}$ (\%) HA-316L composites are passive in Ringer's solution and active in $0.1 \mathrm{M} \mathrm{HCl}$ solution which simulates occluded cell corrosion conditions.

The corrosion resistance decreases with increasing HA content in both solutions.

Sintered 316L stainless steel and 5, 20 and $50 \mathrm{wt}$. (\%) HA-316L composites are highly corrosion resistant in Ringer's solution.

Only 316L stainless steel and 5 wt. (\%) HA-316L composite can be considered corrosion resistant in $0.1 \mathrm{M}$ $\mathrm{HCl}$ solution.

9. Fan X, Chen J, Zou J, Wan Q, Zhou Z and Ruan J. Bone-like apatite formation on HA/316L stainless steel composite surface in simulated body fluid. Transactions of Nonferrous Metals Society of China. 2009; 19:347-52. http://dx.doi.org/10.1016/ S1003-6326(08)60276-9

10. Szewczyk-Nykiel A and Nykiel M. Study of hydroxyapatite behavior during sintering of 316L steel. Archives of Foundry Engineering. 2010; 10:235-40.

11. Fontana MG. Corrosion Engineering. New York: MacGrawHill Book Company; 1986.

12. Tulinski M and Jurczyk M. Corrosion resistance of nickel-free austenitic stainless steels/hydroxyapatite composites. Physica Status Solidi C. 2010; 7:1359-62. http://dx.doi.org/10.1002/ pssc. 200983351

13. Tulinski M and Jurczyk M. Corrosion resistance of nickelfree austenitic stainless steels and their nanocomposites with hydroxyapatite in Ringer's solution. Materials Science Forum. 2011; 674:159-63. http://dx.doi.org/10.4028/www. scientific.net/MSF.674.159

14. Silva G, Baldissera MR, Trichês ES and Cardoso KR. Preparation and characterization of stainless steel 316L/HA biocomposite. Materials Research. 2013; 16(2):304-309. http:// dx.doi.org/10.1590/S1516-14392012005000182

15. International Centre for Diffraction Data. JCPDS-ICDD, PCPDFWIN version 2.1. Swarthmore; 2000.

16. Pourbaix M. Atlas of Electrochemical Equilibria in Aqueous Solutions. Oxford: Pergamon Press; 1966.

17. Olsson COA and Landolt D. Passive films on stainless steels- Chemistry, structure and growth. Electrochimica Acta. 2003; 48:1093-104. http://dx.doi.org/10.1016/S00134686(02)00841-1

18. Talha M, Behera CK and Sinhá OP. Potentiodynamic polarization study of Type 316L and 316LVM stainless steels for surgical implants in simulated body fluids. Journal of Chemical Pharmaceutical Research. 2012; 4:203-8. 